\title{
REPRESENTASI REKAYASA SOSIAL SEBAGAI SARANA KEADILAN HUKUM
}

\author{
Yayuk Kusumawati \\ Institut Agama Islam (IAI) Muhammadiyah Bima \\ Jl. Anggrek No. 16 Ranggo Na'e Kota Bima \\ yayukalkhansa@gmail.com
}

\begin{abstract}
:
In the social life, there is circulation life which change quickly and slowly, so the system of law in Indonesia should be adjusted unnamed conservative. To answer that challenge, needed the social engineering in the social life to fulfill their goals. Social engineering presented to solve problem in social life. Principle, fungtion of the low to be able to change the symbol or method in social life, it can make the habitual become strong or more loyalited and may be the other habitual which happen in social life. That condition, such as deleted the habitual which not match to social need or create new habitual which though more benefit and kindness than before. Refer to the dynamic social circulation, the changing is a necessary. In this term, fungtion of the low must be maximalized for justice and peace, it is mean to social wealth.
\end{abstract}

Keywords: Justice, Low, Social engineering

\section{Pendahuluan}

Hukum menurut adalah perlindungan pada manusia yang berbentuk kaidah dan norma ${ }^{1}$. Dengan adanya kaidah norma yang berlaku dalam masyarakat yang dijewantahkan dalam sebuah aturan yang disebut dengan hukum, bukan berarti kondisi masyarakat akan terhindar dari konflik sosial, justru konflik yang terjadi seperti siklus kehidupan kadang damai, tentram dan kemudian konflik.

Kompleksitas problem sosial yang terjadi di kalangan masyarakat baik itu dalam bidang sosial, politik, pendidikan, agama, ekonomi dan lain sebagainya. Sehingga diperlukan upaya untuk memecahkan masalah dan memperbaiki sistem sosial yang mengarah kepada kehidupan

${ }^{1}$ Rusli Effendi, Achmad Ali dan Poppy Andi Lolo, Teori Hukum (Makassar : Hasanuddin Universitas Press. Ujung pandang, 1991), hlm 81 
masyarakat yang ideal. Hal ini harus diimbangi dengan langkah konkret yang memiliki visi dan misi yang jelas. Sehingga rencana untuk mengubah setting pola pikir masyarakat dapat berjalan berdasarkan tujuan. Problem sosial yang terjadi disebabkan oleh kesalahan berfikir dan mitos-mitos yang telah berkembang di masyarakat dan di sinilah diperlukannya suatu rekayasa sosial untuk memecahkan masalah tersebut. Disamping itu diperlukan agen-agen yang mampu memberikan solusi dalam pemecahan masalah sosial yang berperan sebagai pembaharu dan bergerak dalam upaya rekayasa sosial yang bersifat positif.

Roscoe Pound menyatakan bahwa fungsi hukum adalah social engineering atau rekayasa sosial. Dalam pemikirannya ia menyatakan bahwa putusan hukum yang dijatuhkan oleh hakim diharapkan mampu merubah perilaku manusia. Pendapat Roscoe Pound tersebut benar ketika ia memandang hukum sebagai sebuah putusan-putusan hakim dalam sistem hukum anglo saxon atau common law ${ }^{2}$.

Pernyataan Roscoe Pound tersebut pada awal orde baru dibawa ke Indonesia oleh pakar-pakar hukum saat itu dengan pemikiran bahwa hukum merupakan alat rekayasa sosial. Dalam sistem hukum sipil (civil law system) yang diterapkan di Indonesia, yang menganut model hukum Eropa, hukum adalah sebuah aturan Undang-undang yang notabene merupakan produk kekuasaan penguasa. Dalam konteks ini, maka hukum diterapkan oleh penguasa yang memiliki kewenangan membentuk hukum, dan demi hukum siapapun harus tunduk terhadap aturan hukum tersebut.

Pada kondisi yang demikian maka hukum menjadi alat pengendali penguasa terhadap rakyatnya. Hukum menjadi alat legitimasi penguasa untuk berbuat terhadap rakyatnya. Ketika kekuasaan berada di tangan orang-orang yang zalim maka hukum akan begitu ditakuti. Penguasa yang zalim akan menggunakan hukum untuk berbuat sesuai dengan kehendaknya nyaris tanpa kendali, hal ini terjadi di banyak negara berkembang yang mengadopsi teori Roscoe Pound tersebut. Ketika fenomena Reformasi menyeruak di Indonesia, maka teori ini dijadikan sebagai salah satu kesalahan besar bidang hukum yang telah melahirkan

${ }^{2}$ Rahardjo Satjipto, 2010. Sosiologi Hukum. Yogyakarta : Genta Publishing hlm. 13

Sangaji Jurnal Pemikiran Syariah dan Hukum 
penguasa yang out of control. Dalam hal ini rupanya telah terjadi kesalahpahaman atas konsep berfikir Roscoe Pound tersebut. Teori Roscoe Pound yang sangat fenomenal tersebut lahir dari sebuah sistem yang berbeda dengan sistem yang kita anut. Ia lahir dari sebuah sistem hukum common law yang menganggap bahwa hukum adalah putusan yang dijatuhkan oleh hakim (Hukumnya Hakim). Roscoe Pound lahir dalam dunia hukum yang menganggap bahwa hukum itu dibentuk oleh kekuasaan hakim, bukan penguasa eksekutif.

Hukum dalam sistem common law, dibentuk oleh hakim, para pihak yang mengajukan masalah kepada pengadilan memohon keadilan agar diputuskan mana yang benar dan adil oleh para hakim. Hakim kemudian akan memeriksa kasus tersebut dan kemudian akan memutuskan apa yang seharusnya dipatuhi oleh para pihak. Hakim membentuk hukum berdasarkan putusan hakim yang diharapkan akan merubah perilaku para pihak yang awalnya tidak mengetahui yang benar menurut hukum, dan kemudian akan bertindak serta berperilaku menurut hukum. Sehingga hukum mendidik ia untuk faham akan hukum.

Secara langsung dapat dikatakan bahwa putusan pengadilan tersebut (law) diharapkan telah mampu merekayasa atau merubah perilaku (engineering) masyarakat. Dalam hal ini tidak ada unsur power penguasa untuk menekan kehendaknya terhadap rakyat, melainkan hakim yang faham hukum mendidik masyarakat bagaimana berperilaku yang sepatutnya. Hakim mendidik para pihak untuk berperilaku yang awalnya di luar hukum menjadi manusia yang sadar hukum di tengah masyarakat.

Konsep pemikiran Roscoe Pound ini menjadi salah kaprah ketika dimasukkan dalam sistem hukum yang berbeda yaitu sistem civil law yang memandang hukum yang utama adalah putusan penguasa dan bukan putusan hakim dalam sidang pengadilan. Ketika diterapkan dalam sistem yang berbeda ternyata menghasilkan makna yang sangat berbeda dari makna penerapan hukum yang dimaksud oleh Roscoe Pound. Roscoe Pound tentunya tidak pernah membayangkan bahwa teorinya akan melahirkan penguasa yang absolut, karena ia hanya berfikir bahwa hukum itu hakim bukan penguasa. 


\section{Hukum Sebagai Sarana Rekayasa Sosial}

Hukum sebagai sarana rekayasa sosial (law as a tool of social engineering) pertama kali dikemukakan Roscoe Pound (1870-1964), pemikir yang jadi pentolan mazhab hukum anthro-sociological jurisprudence. Mazhab ini berkembang di Amerika Serikat sebagai reaksi atas mazhab positivisme hukum yang diprakarsai oleh John Austin (1790-1859) dan Hans Kelsen (1881-1973) pada abad ke-193.

Rekayasa sosial (Social engineering) adalah campur tangan gerakan ilmiah dari visi ideal tertentu yang ditujukan untuk mempengaruhi perubahan sosial. Rekayasa sosial merupakan sebuah jalan mencapai sebuah perubahan sosial secara terencana ${ }^{4}$. Gerakan ilmiah yang dimaksudkan disini adalah sebuah gagasan atas perubahan tingkat/taraf kehidupan masyarakat demi tercapainya kesejahteraan dan kemandirian. Masyarakat pada umumnya menginginkan adanya perubahan sosial ke arah yang lebih baik sehingga perubahan sosial harus dapat dilakukan secara berkesinambungan dan terencana

Rekayasa sosial terjadi karena terdapat beberapa kesalahan pemikiran manusia dalam memperlakukan masalah sosial yang disebut para ilmuwan dengan sebutan intellectual cul-de-sac yang menggambarkan kebuntuan berpikir. Salah satu bentuk kesalahan pemikiran lainnya adalah permasalahan sosial yang kerap dikait-kaitkan dengan mitos ataupun kepercayaan manusia akan suatu gerakan abstrak 'ilusi' yang tanpa disadari dapat merubah tatanan kehidupan bermasyarakatnya. Untuk itu perlu diadakannya rekayasa sosial agar kesalahan-kesalahan berpikir seperti ini dapat diatasi sehingga masyarakat dapat melihat permasalahan yang dihadapinya sebagai sesuatu yang konkrit ${ }^{5}$.

Rekayasa sosial timbul akibat adanya sentimen atas kondisi manusia. Untuk itu perlu adanya perombakan yang dimulai dari cara pandang/paradigma manusia atas sebuah perubahan. Pandangan Pound tersebut agaknya bertolak dari pendekatan instrumentalisme hukum

${ }^{3}$ Said Romadlan, 2013. Rekayasa Sosial (Social Engineering) Adopsi Teknologi Komunikasi (Internet) di Kalangan Pondok Pesantren Muhammadiyah, Program Studi Ilmu Komunikasi FISIP UHAMKA, Jurnal Letmit UHAMKA.

${ }^{4}$ Rahardjo Satjipto, 2010. Sosiologi Hukum. Yogyakarta : Genta Publishing hlm 90 hlm 71

${ }^{5}$ Kamil Ahmad dan Fauzan, 2008. Kaidah-kaidah Hukum Yurisprudensi. Jakarta : Kencana.

Sangaji Jurnal Pemikiran Syariah dan Hukum 
yang selalu berkutat pada proposisi bahwa, pertama, hukum memuat sumber doktrinal yang berupa nilai dan asas-asas yang memberikan isi dan bentuk pada perkembangan hukum. Kedua, hukum selalu bersifat dinamis, tidak statis, dan secara alamiah selalu dalam keadaan berkembang. Ketiga, hukum senantiasa berkembang secara teratur dalam suatu sistem hukum untuk menghadapi tuntutan kemanusiaan. Keempat, adalah tugas hukum untuk memelihara dan menjaga agar proses perkembangan hukum dapat teratur dan bekerja secara bebas ${ }^{6}$.

\section{Akibat yang dikehendaki dari hukum sebagai sarana rekayasa sosial}

Penggunaan hukum sebagai sarana rekayasa sosial tidak dapat dilepaskan dari anggapan serta faham bahwa hukum itu merupakan sarana yang dipakai untuk mencapai tujuan-tujuan yang jelas. Dengan demikian, maka hukum sudah memasuki kawasan politik, karena hukum sudah menjadi sarana implementasi keputusan-keputusan politik, dampaknya pun dapat bersifat positif dan negative antara lain sebagai berikut ${ }^{7}$ :

a. Dampak positif

Untuk merubah pola-pola tertentu dalam suatu masyarakat, baik dalam arti mengokohkan suatu kebiasaan menjadi sesuatu yang lebih diyakini dan lebih ditaati, maupun dalam bentuk perubahan lainnya. Perubahan lainnya dimaksud, antara lain menghilangkan suatu kebiasaan yang memang sudah dianggap tidak sesuai dengan kondisi masyarakat, maupun dalam membentuk kebiasaan baru yang dianggap lebih sesuai, atau dapat mengarahkan masyarakat ke arah tertentu yang dianggap lebih baik dari sebelumnya.

b. Dampak Negatif

Rekayasa Sosial dalam suatu masyarakat tidak hanya memiliki dampak positif, tetapi juga memiliki dampak yang negatif yang timbul yaitu antara lain:

Pertama sebagai suatu prosedur, suatu cara untuk mengubah

\footnotetext{
${ }^{6}$ Johnson Alvin S, 2004. Sosiologi Hukum. Jakarta : PT Rineka Cipta

7 Achmad Ali, Menguak Tabir Hukum; Suatu Kajian Filosofis dan Sosiologis (Jakarta: Chandra Pratama, 1996), h. 97.
} 
masyarakat, karena cara mengubah masyarakat tidak lah mudah otomatis masyarakat akan ada yang setuju dan tidak setuju dan kemudian munculah ketimpangan sosial yang terjadi, sehingga masyarakat ada yang melanggar hukum dan sebagainya dan yang. Kedua yang teramat penting adalah secara materil, yaitu masyarakat apa yang dikehendaki. Itu tidak mudah, kita harus bertanya macam masyarakat apa yang dikehendaki oleh pemerintah dan oleh warga masyarakat".

Disini akan timbul pertentangan-pertentangan dengan nilai sebagai paradigma hukum. Paradigma nilai selalu ingin mengontrol hukum dari nilai yang dijunjungnya dan dengan demikian menjadi kaidah tolak ukur. Seperti dalam doktrin Rul Of Law , kontrol tersebut dikehendaki untuk mengendalikan kekuasaan untuk tidak bebas mengatur sepeti yang dikehendakinya. dipertanyakan legitimasi berdasarkan nilai-nilai tertentu.

Kritik dan kontrol dari sudut nilai tersebut tidak menjadi pusat perhatian apabila orang memasuki penggunaan hukum sebagai sarana rekayasa sosial.

Penggunaan hukum sebagai rekayasa sosial membawa kita mengenai kaitan antara pembuatan hukum atau cara-cara yang dilakukan oleh hukum dengan hasil atau akibat yang kemudian muncul.

\section{Langkah-langkah dalam rekayasa sosial tersebut adalah sebagai berikut:}

Adam Podgorecki mengajukan beberapa langkah yang harus ditempuh, apabila pembuatan hukum ingin memberikan akibat seperti dikehendaki. Langkah-langkah dalam rekayasa sosial tersebut adalah sebagai berikut:

1. Mendeskripsikan situasi yang dihadapi dengan baik.

2. Analisis terhadap penilaian-penilaian mengenai situasi tersebut dan menentukan jenjang susunannya.

3. Melakukan verifikasi hipotesa-hipotesa

4. Pengukuran efek hukum yang dibuat ${ }^{8}$.

${ }^{8}$ Rahardjo Satjipto .2012. Ilmu Hukum. Bandung : PT Citra Aditia Bakti. Hlm 218

Sangaji Jurnal Pemikiran Syariah dan Hukum 


\section{Fungsi Hukum sebagai Alat Rekayasa Sosial}

Di dalam menyesuaikan diri dengan perubahan kehidupan, fungsi hukum sebagai a tool of engineering, sebagai perekayasa sosial, sebagai alat untuk merubah masyarakat ke suatu tujuan yang diinginkan bersama, sangat berarti". ini menunjukkan bahwa hukum sebagai alat rekayasa sosial sangat diperlukan dalam proses perubahan masyarakat yang di manapun senantiasa terjadi, apalagi dalam kondisi kemajuan yang menuntut perlunya perubahan-perubahan yang relatif cepat ${ }^{9}$.

Fungsi Hukum sebagai alat rekayasa sosial ini, juga sering disebut sebagai a tool of engineering yang pada prinsipnya merupakan fungsi hukum. Menyatakan bahwa "Hukum sebagai sarana rekayasa sosial, inovasi, sosial engineering, tidak saja digunakan untuk mengukuhkan pola-pola kebiasaan dan tingkah laku yang terdapat dalam masyarakat, melainkan juga untuk mengarahkan pada tujuan-tujuan yang dikehendaki, menghapuskan kebiasaan-kebiasaan yang dipandang tidak perlu lagi, menciptakan pola-pola kelakuan baru dan sebagainya"10.

Dalam kaitan ini, dapat dimaklumi bahwa ditinjau dari segi eksistensi perubahan yang merupakan sesuatu yang harus terjadi, maka fungsi hukum menjadi semakin penting dan menentukan, terutama lagi dalam era reformasi yang digulirkan dewasa ini, atau era pembangunan yang berkesinambungan.

Fungsi hukum sebagai alat rekayasa sosial yang semakin penting dalam era pembangunan tersebut, hukum sebagai tata kaidah dapat berfungsi untuk menyalurkan arah-arah kegiatan warga masyarakat ke tujuan yang dikehendaki oleh perubahan tersebut. Sudah tentu bahwa fungsi hukum di atas seyogyanya dilakukan, di samping fungsi hukum sebagai sistem pengendalian sosial"11. Ini berarti bahwa disamping fungsi hukum sebagai alat pengendalian sosial, juga salah satu fungsi lainnya yang sangat penting dan bahkan justru harus dilaksanakan dalam era pembangunan, adalah fungsinya sebagai alat rekayasa sosial. Tentu saja

${ }^{9}$ Wawan E. Kuswandoro, (2002), Rekayasa Sosial, Surabaya: Fakultas Ilmu Sosial dan Ilmu Politik: Universitas Brawijaya, Malang. Hlm 24 Hlm 30

${ }^{10}$ Satjipto Rahardjo Rahardjo Satjipto, 2010. Sosiologi Hukum. Yogyakarta : Genta Publishing.

11 Jalaluddin Rakhmat, Rekayasa Sosial: Reformasi, Revolusi atau Manusia Besar, Rosda (Bandung:1999). 
sebagai alat rekayasa harus diarahkan kepada hal-hal yang positif dan bukan sebaliknya.

Walaupun sejumlah ahli memberikan pandangan positif terhadap fungsi hukum sebagai sarana rekayasa sosial ini, namun fungsi tersebut tidak luput dari kritikan atau kelemahannya. Terhadap tanggapan dimaksud, seperti dikemukakan oleh Daniel S. Lev yang dikutip oleh Ali Zainudin dengan menyatakan bahwa "membicarakan hukum sebagai rekayasa sosial itu berarti memberikan kekuasaan yang amat penuh kepada pemerintah. Kita selalu menggunakan istilah itu sebagai sesuatu yang netral, padahal dipakainya istilah itu sebenarnya tidak netral. Istilah itu dapat dipakai untuk tujuan yang baik dan dapat juga dipakai untuk tujuan yang buruk. Istilah itu sendiri mempunyai dua arti, pertama sebagai suatu prosedur, suatu cara untuk mengubah masyarakat, dan yang kedua yang teramat penting adalah secara materiil, yaitu masyarakat apa yang dikehendaki. Itu tidak mudah, kita harus bertanya macam masyarakat apa yang dikehendaki oleh pemerintah dan oleh warga masyarakat"12.

Pandangan yang dikemukakan terakhir di atas, menunjukkan bahwa fungsi hukum sebagai alat rekayasa sosial mempunyai arti yang tidak selalu positif, dan bahkan dapat diartikan negatif, terutama karena ketidakjelasan arah yang akan dituju oleh hukum dalam merekayasa masyarakat yang bersangkutan.

Dengan mengemukakan sejumlah contoh, menyatakan adanya kerugian dan keuntungan fungsi hukum sebagai alat rekayasa sosial, seperti yang diungkapkannya bahwa "Contoh dampak positif penggunaan hukum sebagai rekayasa sosial antara lain :

a. Putusan Mahkamah Agung Amerika Serikat pada tahun 1954 yang menetapkan bahwa orang kulit hitam harus dipersamakan dengan orang kulit putih.

b. Undang-Undang dan Peraturan-Peraturan lain mengenai lingkungan hidup.

c. dan sebagainya.

Dampak negatif dari penggunaan hukum sebagai rekayasa sosial

${ }^{12}$ Ali Zainuddin, 2009. Sosiologi Hukum. Jakarta : Sinar Grafika.104

Sangaji Jurnal Pemikiran Syariah dan Hukum 
adalah yang hanya membawa keuntungan bagi sebagian kecil warga masyarakat dunia, justru merugikan sebagian besar warga masyarakat lainnya"13.

Dengan pandangan tersebut, maka dapat dikatakan, bahwa fungsi hukum sebagai sarana atau alat rekayasa sosial dalam aplikasinya perlu dilakukan secara ektra hati-hati, sehingga sejauh mungkin tidak membawa dampak negatif sebagaimana yang dikhawatirkan, dan bahkan jika perlu dalam pelaksanaannya benar-benar tidak akan melahirkan dampak seperti tersebut.

Belajar pada pengalaman dan dari sejumlah contoh yang dianggap negatif kaitannya dengan fungsi hukum sebagai alat rekayasa sosial ini, maka memang masih ada upaya yang dilakukan agar implikasi fungsi hukum tersebut tidak terarah kepada hal-hal yang negatif.

Satjipto Raharjo mengemukakan pandangan Daniel S. Lev yang pada dasarnya memberikan sejumlah pertimbangan, jika akan melaksanakan fungsi hukum sebagai alat rekayasa sosial. Dengan kata lain, agar rekayasa sosial tidak mengarah kepada sesuatu yang dinilai negatif, perlu dilakukan langkah-langkah tertentu seperti yang dikemukakan dalam tulisan dimaksud ${ }^{14}$.

Namun yang paling penting dalam kaitan ini adalah perlunya semua pihak yang terkait dengan aplikasi hukum di tengah masyarakat, benar-benar konsisten, baik dalam arti kejujuran, kesamaan pandangan, kerjasama, dan berbagai prinsip efektivitas lainnya. Seperti halnya Lawrence, William Dahl seorang penulis asal Austria juga pernah menyebut perubahan sosial dengan sebutan "changed of law" atau perubahan hukum/aturan. Perubahan yang dimaksudkan disini adalah efek dari perubahan sosial yang dihasilkan dari rekayasa sosial itu sendiri. Hukum merupakan alat utama dari hasil rekayasa sosial yang kemudian dijadikan dasar terbentuknya suatu masyarakat yang sejahtera karena aturan-aturan yang diterapkan ditujukan untuk terciptanya sebuah keteraturan dalam kehidupan bermasyarakat ${ }^{15}$.

\footnotetext{
${ }^{13}$ Idem hlm 87

${ }^{14}$ Rahardjo Satjipto. 2012. Ilmu Hukum. Bandung : PT Citra Aditia Bakti. hlm 216

${ }^{15}$ Kelsen Hans, 1978. Pure Theori Of Law. Berkely : University California Press hlm.40
} 


\section{Rekayasa Sosial Sebagai Sarana Keadilan Hukum}

Hans Kelsen dalam bukunya general theory of law and state, berpandangan bahwa hukum sebagai tatanan sosial yang dapat dinyatakan adil apabila dapat mengatur perbuatan manusia dengan cara yang memuaskan sehingga dapat menemukan kebahagian di dalamnya ${ }^{16}$. Pandangan Hans Kelsen ini pandangan yang bersifat positifisme, nilainilai keadilan individu dapat diketahui dengan aturan-aturan hukum yang mengakomodir nilai-nilai umum, namun tetap pemenuhan rasa keadilan dan kebahagiaan diperuntukkan tiap individu.

Lebih lanjut Hans Kelsen mengemukakan keadilan sebagai pertimbangan nilai yang bersifat subjektif. Walaupun suatu tatanan yang adil yang beranggapan bahwa suatu tatanan bukan kebahagiaan setiap perorangan, melainkan kebahagiaan sebesar-besarnya bagi sebanyak mungkin individu dalam arti kelompok, yakni terpenuhinya kebutuhankebutuhan tertentu, yang oleh penguasa atau pembuat hukum, dianggap sebagai kebutuhan-kebutuhan yang patut dipenuhi, seperti kebutuhan sandang, pangan dan papan. Tetapi kebutuhan-kebutuhan manusia yang manakah yang patut diutamakan. Hal ini dapat dijawab dengan menggunakan pengetahuan rasional, yang merupakan sebuah pertimbangan nilai, ditentukan oleh faktor-faktor emosional dan oleh sebab itu bersifat subjektif ${ }^{17}$.

Sebagai aliran posiitivisme Hans Kelsen mengakui juga bahwa keadilan mutlak berasal dari alam, yakni lahir dari hakikat suatu benda atau hakikat manusia, dari penalaran manusia atau kehendak Tuhan. Pemikiran tersebut diesensikan sebagai doktrin yang disebut hukum alam. Doktrin hukum alam beranggapan bahwa ada suatu keteraturan hubungan-hubungan manusia yang berbeda dari hukum positif, yang lebih tinggi dan sepenuhnya sahih dan adil, karena berasal dari alam, dari penalaran manusia atau kehendak Tuhan ${ }^{18}$.

Pemikiran tentang konsep keadilan, Hans Kelsen yang menganut aliran positifisme, mengakui juga kebenaran dari hukum alam. Sehingga pemikirannya terhadap konsep keadilan menimbulkan dualisme antara

\footnotetext{
${ }^{16}$ Ibid hlm 45

${ }^{17}$ Ibid hlm 50

${ }^{18}$ Ibid hlm 52
} 
hukum positif dan hukum alam.

Menurut Hans Kelsen ${ }^{19}$ :

"Dualisme antara hukum positif dan hukum alam menjadikan karakteristik dari hukum alam mirip dengan dualisme metafisika tentang dunia realitas dan dunia ide model Plato. Inti dari filsafat Plato ini adalah doktrinnya tentang dunia ide. Yang mengandung karakteristik mendalam. Dunia dibagi menjadi dua bidang yang berbeda: yang pertama adalah dunia kasat mata yang dapat ditangkap melalui indera yang disebut realitas; yang kedua dunia ide yang tidak tampak."

Dua hal lagi konsep keadilan yang dikemukakan oleh Hans Kelsen: pertama tentang keadilan dan perdamaian. Keadilan yang bersumber dari cita-cita irasional. Keadilan dirasionalkan melalui pengetahuan yang dapat berwujud suatu kepentingan-kepentingan yang pada akhirnya menimbulkan suatu konflik kepentingan. Penyelesaian atas konflik kepentingan tersebut dapat dicapai melalui suatu tatanan yang memuaskan salah satu kepentingan dengan mengorbankan kepentingan yang lain atau dengan berusaha mencapai suatu kompromi menuju suatu perdamaian bagi semua kepentingan ${ }^{20}$.

Kedua, konsep keadilan dan legalitas. Untuk menegakkan di atas dasar suatu yang kokoh dari suatu tatanan sosial tertentu, menurut Hans Kelsen pengertian "Keadilan" bermaknakan legalitas. Suatu peraturan umum adalah "adil" jika ia bena-benar diterapkan, sementara itu suatu peraturan umum adalah "tidak adil" jika diterapkan pada suatu kasus dan tidak diterapkan pada kasus lain yang serupa. Konsep keadilan dan legalitas inilah yang diterapkan dalam hukum nasional bangsa Indonesia, yang memaknai bahwa peraturan hukum nasional dapat dijadikan sebagai payung hukum (law unbrella) bagi peraturan-peraturan hukum nasional lainnya sesuai tingkat dan derajatnya dan peraturan hukum itu memiliki daya ikat terhadap materi-materi yang dimuat (materi muatan) dalam peraturan hukum tersebut ${ }^{21}$.

\footnotetext{
${ }^{19}$ Ibid hlm 54

${ }^{20}$ Ibid hlm 62

${ }^{21}$ Ibid hlm 65
} 


\section{Penutup}

Rekayasa sosial merupakan alat yang mampu mengintegrasikan masyarakat, hal ini dikarenakan adanya tujuan yaitu perubahan ataupun mengendalikan stagnasi akibat keadaan yang telah memenuhi syarat sebagai masyarakat yang sejahtera. Namun perlu kehati-hatian dalam penerapan hukum sebagai sarana rekayasa sosial dikarenakan akan menimbulkan dampak yang tidak dinginkan, semua wacana yang dikembangkan ini merupakan tuntutan masyarakat ke depannya agar menjadi masyarakat yang sejahtera sesuai dengan tuntutan zaman.

Hukum sebagai sarana rekayasa social adalah untuk menimbulkan kondisi tertentu yang mengarahkan pada pencapaian tujuan hukum yang diprioritaskan serta sekaligus mengendalikan kehidupan social dalam masyarakat yang direncanakan menuju kehidupan yang lebih baik. Hukum sebagai rekayasa social dalam pembangunan hukum nasional tidak saja menciptakan perundang-undangan hukum nasional yang baru, tetapi juga menghasilkan perundang-undangan yang tidak mengenyampingkan hak-hak asasi manusia.

\section{Daftar Pustaka}

Ali Zainuddin, 2009. Sosiologi Hukum. Jakarta: Sinar Grafika

Achmad Ali, 1996. Menguak Tabir Hukum; Suatu Kajian Filosofis dan Sosiologis Jakarta: Chandra Pratama

Johnson Alvin S, 2004. Sosiologi Hukum. Jakarta: PT Rineka Cipta

Jalaluddin Rakhmat, 1999. Rekayasa Sosial: Reformasi, Revolusiatau Manusia Besar, Bandung : Rosda.

Kelsen Hans, 1978. Pure Theori Of Law. Berkely: University California Press

Hans Kelsen, 2011. General Theory of Law and State, diterjemahkan oleh Rasisul Muttaqien, Bandung, Nusa Media.

Kamil Ahmad dan Fauzan, 2008. Kaidah-kaidah Hukum Yurisprudensi. Jakarta: Kencana.

Rahardjo Satjipto, 2010. Sosiologi Hukum. Yogyakarta: Genta Publishing 2012. Ilmu Hukum. Bandung: PT Citra Aditia Bakti

Rusli Effendi, Achmad Ali dan Poppy Andi Lolo, 1991. Teori Hukum (Makassar: Hasanuddin Universitas Press. Ujung pandang, 
Saifullah, 2007. Refleksi Sosiologi Hukum. Bandung : PT Refika Aditama Said Romadlan, 2013. Rekayasa Sosial (Social Engineering) Adopsi Teknologi Komunikasi (Internet) di Kalangan Pondok Pesantren Muhammadiyah, Program Studi Ilmu Komunikasi FISIP UHAMKA, Jurnal Letmit UHAMKA.

Wawan E. Kuswandoro, 2002, Rekayasa Sosial, Surabaya: Fakultas Ilmu Sosial dan Ilmu Politik: Universitas Brawijaya, Malang. 